\title{
ANALYSIS OF THE SEROLOGICAL AND HEMATOLOGICAL CRITERIA IN THE PATIENTS WITH SYSTEMIC LUPUS ERYTHEMATOSUS IN AN AMAZONAS'S UNIVERSITY HOSPITAL
}

Samuel Elias Basualto Dias (UNIVERSIDADE FEDERAL DO AMAZONAS, MANAUS, AM, Brasil), Igor Oliveira da Silva (UNIVERSIDADE FEDERAL DO AMAZONAS, MANAUS, AM, Brasil), Maria Victória Emanuelli Queiroz (UNIVERSIDADE FEDERAL DO AMAZONAS, MANAUS, AM, Brasil), Clara Pinheiro Martins (UNIVERSIDADE FEDERAL DO AMAZONAS, MANAUS, AM, Brasil), Andrezza Mendes Franco (UNIVERSIDADE FEDERAL DO AMAZONAS, MANAUS, AM, Brasil), Vitória Miki Pang Takatani (UNIVERSIDADE FEDERAL DO AMAZONAS, MANAUS, AM, Brasil), Bárbara Letícia Silva Costa (UNIVERSIDADE FEDERAL DO AMAZONAS, MANAUS, AM, Brasil), Vitor Matheus Orlando Sampaio (UNIVERSIDADE FEDERAL DO AMAZONAS, MANAUS, AM, Brasil), Domingos Sávio Nunes de Lima (UNIVERSIDADE FEDERAL DO AMAZONAS, MANAUS, AM, Brasil)

\section{BACKGROUND}

Systemic Lupus Erythematosus (SLE) is an inflammatory, chronic, autoimmune disease with polymorphic manifestations. The American College of Rheumatology defined the diagnostic guidelines for SLE, including the presence of immunological and hematological changes. The objective of this study is to discuss the types of Serologic and Hematologic Alterations found in patients with SLE that are attended at a university hospital in Manaus / Amazonas.

\section{MATERIALS AND METHODS}

It is a retrospective, observational, transversal and descriptive study, based on the analysis of medical records of patients with SLE in follow-up at the Rheumatology Service of a University Hospital of Manaus - Amazonas. The data collected were as follows: Serological: anti-native DNA, anti-SM, anticardiolipin IgG or IgM, lupus anticoagulant, anti-Ro, anti-La and anti-RNP; and Hematologic: Autoimmune Hemolytic Anemia (AIHA), Immune Thrombocytopenic Purpura (ITP), Leucopenia, Lymphopenia, Plaquetopenia, Pancytopenia, Hypocomplementemia and Coombs D. This study was approved by the Research Ethics Committee.

\section{RESULTS}

A total of 595 medical records were observed, with 282 serological tests positive for SLE: 196 carriers of native anti-DNA, 48 anti-nevirapine, 40 Anti-Ro, 35 anti-SM, 10 anti-RNP, 9 anti-coagulant Lupus and 8 Anti-La. Regarding the hematological manifestations, 290 patients had such complications: 125 had AIHA, 77 Lymphopenia, 72 Leukopenia, 45 thrombocytopenia, 31 Hipocomplementenemia, 20 Coombs D positive, 13 ITP, and 9 Pancytopenia.

\section{CONCLUSION}

It is verified that the most prevalent serology is the native Anti-DNA, associated with renal injury. The presence of Anticardiolipin and Lupus Anticoagulant is related to susceptibility to Antiphospholipid Antibody Syndrome (APS). Anti-Ro and Anti-La show a possible association with Sjogren's Syndrome, and cases with anti-RNP positive associated with mixed connective tissue disease, reaffirming the thesis that many patients with SLE present a second disorder. Moreover, it is observed that the most common hematological alteration is AIHA. It is also contemplated that all changes described in the ACR guidelines are present. In addition, the difference in the number of cases with AHAl and patients with positive Coombs positive is observed, since this is characteristic of AHAl, that is, in the majority of AHAl cases the presence of the antibody against the red blood cell was not identified. It is concluded that the data observed are in agreement with those in the literature. 